\title{
David Cameron, Citizenship and the Big Society: a New Social Model?
}

David Cameron, citoyenneté et le programme Big Society : un nouveau modèle social?

\section{Raphaële Espiet-Kilty}

\section{(2) OpenEdition}

\section{Journals}

Electronic version

URL: http://journals.openedition.org/rfcb/796

DOI: $10.4000 / \mathrm{rfcb} .796$

ISSN: 2429-4373

Publisher

CRECIB - Centre de recherche et d'études en civilisation britannique

Electronic reference

Raphaële Espiet-Kilty, « David Cameron, Citizenship and the Big Society: a New Social Model? », Revue Française de Civilisation Britannique [Online], XXI-1 | 2016, Online since 20 July 2016, connection on 19 April 2019. URL : http://journals.openedition.org/rfcb/796 ; DOI : 10.4000/rfcb.796

This text was automatically generated on 19 April 2019

Licence Creative Commons

Revue française de civilisation britannique est mis à disposition selon les termes de la licence Creative Commons Attribution - Pas d'Utilisation Commerciale - Pas de Modification 4.0 International. 


\section{David Cameron, Citizenship and the Big Society: a New Social Model?}

David Cameron, citoyenneté et le programme Big Society : un nouveau modèle social?

Raphaële Espiet-Kilty

\section{Introduction}

1 In 1994, Robert Harmel and Kenneth Janda defined party change as "alteration or modification in how parties are organised, what human and material resources they can draw upon, what they stand for and what they do." They further argue that change must be driven by something for parties do not easily change just for the sake of it. ${ }^{2}$ Because it is difficult to study all the variables that are at play in driving change, scholars generally focus on just three drivers which Harmel and Janda define as: (i) external shock (electoral defeat being one such), (ii) a change of leader and (iii) change in the dominant faction that runs the party. ${ }^{3}$ After losing first the 1997 general election and then the following two elections (first driver), the Conservative Party, in spite of renewing its leadership three times (second driver) remained unable to convince the public that it was fit to lead the country. David Cameron's election to the head of the party in December 2005 (second driver again) signalled the victory of a new faction (third driver) that undertook the task of convincing the British electorate that the Conservative Party was no longer the "nasty party," i.e. a party that wanted to privatise health and education and that did not have a sympathetic understanding of the difficulties of those at the bottom of society. It therefore seems a plausible hypothesis to suggest that after so many shocks and changes, the party that took the lead of the country after the 2010 general election had changed or was perceived by voters as having changed enough to be trusted again. The only possible way in which it could have done so was by breaking away from Thatcherism in general and in particular from the Thatcherite social model that was supposedly condemned by voters for being "nasty." ${ }^{\prime \prime}$ This was reflected in David Cameron's announcement in August 2008: 
2 [I am going to be] as radical a social reformer as Mrs Thatcher was an economic reformer and radical social reform is what the country needs right now [...] to mend the broken society. ${ }^{5}$

3 Such "radical social reforms," if introduced, would necessarily have an impact on British society and on the citizens that form it. The concept of citizenship is one that is difficult to grasp all the more so as it is not definable in an official way. ${ }^{6}$ From a theoretical point of view, it has very different definitions depending on the geographical area where it is formulated which might explain why Van Gunsten and Leca, for example, judge it “ questionable." As a general rule, however, citizenship is defined by the relationship between the individual and the State, although this relationship may be more or less close. Stewart, for example, speaks of a "democratic citizenship" which he defines as: “ shared membership of a political community and requires non-identification of such political communities and states." 8 In this particular case, the relationship between the citizen and the State is quite loose. He/she evolves in civil society, at the junction between the State and the private sphere. More important than rights, he/she has obligations that range from adopting a civic behaviour to helping members of the community by giving time or money to charities. It is this citizen who was at play in the case of Thatcher's active citizen $^{9}$ as well as in Cameron's Big Society. And in both cases, it is set in sharp opposition to Marshall's social citizen who, rather than obligations, has rights. In his seminal work, ${ }^{10}$ T.H. Marshall defined citizenship as "a status bestowed on those who are full members of a community." 11 This status confers rights to every citizen. These rights have evolved over time and now have three facets to them. The third and most contemporary facet of citizenship, the social element, presents the citizen as able to insist on the right to live in decent or "civilized"12 conditions, which are judged necessary to the full and complete exercise of the other two forms of citizenship. The State's role is to provide these conditions in the name of social justice. This social citizenship is precisely that which Margaret Thatcher was rejecting when she said: "There is no such thing as society" and which is therefore linked to the social project of David Cameron's Big Society, his response to Thatcher's "no society."

4 For Margaret Thatcher, civil society did not exist any more than society for there were only self-reliant and responsible individuals whose moral, and therefore private, duty it was to look after themselves and their families first and then after their neighbours. However, her praise of the Victorian Age as the "charitable age" reveals that, even for her brand of Conservatism, there existed a privileged medium through which individuals could reach to others. In many ways therefore, this absence of civil society shares common features with David Cameron's very real one which is also formed of citizens who are characterised by their obligations to others and who are supported in their actions by civil society. The difference however, is that its role should be enhanced to make it more efficient in delivering social services. This is where the Big Society programme comes in play. In Big Society rhetoric, civil society becomes the third sector formed of a modernised and more competitive voluntary sector - one that has a more market-based approach to delivering services - associated with the newly created social enterprises, which are private companies whose business is to deliver a social service. The brunt of David Cameron's social programme was born of this dedication to creating a " more efficient" third sector.

5 It is noticeable that there is apparently very little difference between Thatcher's active citizen and Cameron's citizen of the Big Society in that in both cases citizenship is based 
on the idea that an individual has obligations rather than rights and that the vessel for the exercise of these obligations is civil society rather than the state or welfare state. This would therefore tend to disqualify the hypothesis that there was a change. Yet, both Prime Ministers belonged to two different Conservative trends. Margaret Thatcher was a neo-liberal Conservative whereas David Cameron is, arguably, a One-Nation Conservative. ${ }^{13}$ This is reflected in their contrasting vision of society and of the role of the state in this respect. However, both Prime Ministers equally condemned the welfare state for being responsible for having destroyed civil society and therefore citizenship. Where Margaret Thatcher simply proposed to reduce the role of the state, David Cameron went further down the same road proposing however to create an alternative to the welfare state, one that would not merely be individuals but a Big Society of active citizens. However, David Cameron's flagship project is now said to be moribund.

6 This paper will first demonstrate that the differences between Margaret Thatcher and David Cameron's social visions were the result of their belonging to two distinct Conservative trends. However, in the case of Cameron, his social vision was not commensurate with his economic one. In addition to being prioritised, the 2010-2015 Coalition Government's economic policies clashed with David Cameron's social agenda thus giving the impression that the Big Society Programme was only a smokescreen to hide drastic public sector cuts. ${ }^{14}$ This impression, though, is not wholly accurate and it will be demonstrated, in the second part, that Cameron's failure to carry through his social agenda was as much because of a lack of theoretical or intellectual drive on his part as because of the pressure that was exerted on him to tone it down. That pressure came both from within his government and from the citizens themselves. Finally, the Big Society programme seemed doomed from the outset not only because most citizens did not adhere to it but also because the voluntary sector was not perceived as the most appropriate medium to relieve poverty especially at times of austerity.

\section{Margaret Thatcher and David Cameron: Two different visions of inequality?}

7 Margaret Thatcher's middle-class ethos set her in opposition to what she claimed was the bourgeois-guilt driven ethos of the One-Nation Conservatives of the 1950s and 1960s. It was that guilt, she argued, that had led them to lending so much moral and economic support to the welfare state during the thirty years of consensus that preceded her election in May 1979. Her first two terms in office were therefore almost solely dedicated to breaking with this consensus that rested on a commitment to full employment and taxand-spend policies that caused what she described in the many speeches she delivered and later in her memoirs as an ever increasing spiral of public spending and state interventionism. Once she believed her governments had succeeded in restoring the economy and in setting Britain on the path of growth, she turned her attention to the lower echelons of the state aiming to impress upon them and the citizens the culture of responsibility and accountability that she believed was the key to social revival. Her main tool was to be the community charge. It was supposed to turn every individual into a citizen, i.e. to turn the "underclass" 15 into responsible taxpayers. By making everyone pay, she was hoping to convince a majority of the necessity to curb public spending at the local level, one more attack on the edifice of the welfare state, which was underpinned, in her own terminology, by local Socialism. The period of the introduction of the community 
charge from 1988 to 1990 was when Margaret Thatcher publicly used the term citizen for the first time. It was also then that she made her interview to a women's magazine during which she famously said: "There is no such thing as society." ${ }^{16}$ Active citizenship was her Government's attempt at spinning their way out of the negative reactions to this declaration. It was not a new notion however. In fact it was rather an old one for the Conservative Party that had a long tradition of supporting the work of charities and of volunteers, Burkes "little platoons" that formed the main part of civil society. Unlike Matthew Hilton and James McKay ${ }^{17}$ who argue that civil society had remained as active during the age of welfare as it had been in the Victorian Age, Margaret Thatcher asserted that the Welfare State had destroyed the civic spirit of the Victorian Age and created, instead of active and responsible citizens, a cohort of assisted and helpless scroungers who lived off state benefits. The Conservative neo-liberals believed that the Welfare State had created a culture of dependency and that it was essential to break this culture by forcing a sense of responsibility onto those who had fallen in its trap. The state, i.e. society had to stop providing for those who should really provide for themselves and active citizens had to play their part in restoring the civic spirit that, according to Margaret Thatcher, was needed to rebuild a caring community spirit: "most Christians would regard it as their personal Christian duty to help their fellow men and women." ${ }^{18}$ In this, she built on the work of Friedrich von Hayek and the Chicago School.

theminal work, Friedrich von Hayek asserts thatice is a mirage, a concept he debars as nonsensical. Social justice, he says, "does not belong to the category of error but to that of nonsense, like the term 'a moral stone." 19 Social justice does not exist because inequality is a natural fact of life. To try and address the problem is necessarily wrong and is necessarily disruptive. In the same vein, in 1983, Margaret Thatcher said:

The nations that have gone for equality, like Communism, have neither freedom nor justice nor equality, they've the greatest inequalities of all, the privileges of the politicians are far greater compared with the ordinary folk than in any other country. ${ }^{20}$

Social justice, as a concept, is based on the assumption that individuals should be allowed to realise their full potential - or exercise their full citizenship rights (Marshall) - in the society where they live and this can only be made possible if all individuals are equally provided with minimum standards determined on the basis of what is "decent" or " civilised" relative to what the majority has. The role of the state should be to guarantee these standards by ensuring that every individual has equal access to education, health care, social security etc., a belief shared, to a certain extent, by the One-Nation Conservatives because it safeguarded social harmony (noticeably not social justice), as illustrated in Disraeli's phrase: "The palace is not safe, when the cottage is not happy." ${ }^{21}$ This was the belief that presided over their supporting of the Welfare State and the belief that, given its name, should have been behind the creation by Iain Duncan Smith and Tim Montgomerie of the Centre for Social Justice (CSJ) in 2004. Of course, both the CSJ's “ Broken Society" 22 and David Cameron's "Big Society" are plays on words to distance a Conservative Party in the making, from Thatcher's "there is no society." But none is fundamentally about social justice. The Conservative Party's social programme was quickly patched together to win the votes of a changing electorate by distancing Cameron's Conservative Party from the burdensome legacy of Thatcherism.

David Cameron needed to address the issue that traditionally divided his party, i.e. inequality, all the more so as, so it seems, an increasing number of British voters were concerned by the widening gap between the super-rich and the rest. ${ }^{23}$ The November 
2009 Big Society speech was to be the instrument of this revival. The vocabulary used borrows from a lexicon that is diametrically opposed to that which Margaret Thatcher used. David Cameron introduces such terms as poverty, solidarity, inequalities, injustice, social progress. The use of such rhetoric enables him to depict himself as heir to Benjamin Disraeli. And indeed, in many ways, this lexicon borrows from that of compassionate conservatism. ${ }^{24}$ However, whilst Disraeli introduced legislation aiming to improve the living conditions of the poor in the areas of housing, health and education, and also to improve their working conditions, the spending cuts implemented at the behest of both Minister for Work and Pensions Iain Duncan Smith and Chancellor George Osborne - cuts in council tax benefits, disabled living allowance, abolition of EMA, a cap on benefits for the unemployed after one year and many others (universal credit etc.) have affected the poorer members of society disproportionally. ${ }^{25}$ This foretold the end to what Cameron called, in his Big Society speech, the Big Government approach. ${ }^{26}$ If David Cameron made use of the language of compassionate Conservatism when speaking of poverty and inequality, the solutions that he envisaged remained fundamentally neoliberal.

\section{Conflicting trends within the Coalition Government}

David Cameron's compassionate Conservatism can be perceived as an instrument that enabled the leader of the Conservative Party to rid himself of the image of heir to Thatcher. To do so, the Big Society borrowed from both New Labour (the Third Way) and David Blunkett's 2003 Civil Renewal Programme, and from Philip Blond's Red Tory. However, it did not match the New Labour Government's financial support of its social programme, nor did it borrow the solutions Blond prescribes to remedy the problem. There are three possible reasons why David Cameron failed to carry through his social agenda.

The first, as contended by many commentators and scholars, is that the Big Society was really only a smokescreen to hide massive public spending cuts especially in the area of welfare. This proposition has been extensively debated. ${ }^{27}$ It is unconvincing, however, for in addition to having been presented before the crisis started biting, the Big Society Programme was a truly Conservative one. It did match a certain Conservative vision of the moral duty of Civil Society in providing for its weaker members. Whether David Cameron really shared this vision or used it as a tool to distance himself from Margaret Thatcher's brand of Conservatism is another issue.

The second is that David Cameron was isolated in a party that fundamentally remained Thatcherite in the image of both its Chancellor of the Exchequer and its Secretary of State for Work and Pensions. In addition, one could add that Cameron's social approach was not coherent. The Big Society programme was flawed from the outset, being a mere patchwork of ideas rather than the result of a consistent vision, ideas that conflicted with the Government's economic policies. This would tend to reinforce the notion that David Cameron's compassionate Conservatism was hesitant at best.

The third is that the electorate, in spite of being apparently critical of the Thatcher legacy, had absorbed most of its precepts and remained too individualistic to form a Big Society. 

would have wanted to reform the welfare state, even if we had no deficit" because "[as] Conservatives, we should hate the idea of people with unfulfilled potential languishing on welfare" adding that the aim of welfare reform was to cut "the cost of social failure" and to help people out of the dependency trap. That is not compassionate Conservatism. The theory of the dependency culture associated with that of the poverty turned dependency trap was one of Margaret Thatcher's recurring themes during the debate over the community charge. It consisted in blaming those on welfare benefits for their plight, in depicting them as undeserving or as Duncan Smith put it, as the actors of their own "worklessness" and of their own downfall into crime: "gangs, debt and drugs," a description that is reminiscent of Keith Joseph's cycle of criminality or of Margaret Thatcher's "deviant behaviour." These are the kinds of prejudices that underpin such shows as the Channel 4 programme Benefits Street, or that are betrayed by such newspaper headlines as: "Vile Product of Welfare UK: Man who bred 17 babies by 5 women to milk benefits system is guilty of killing 6 of them." ${ }^{28}$ The two Coalition Government members in charge of social reform and the budget were ${ }^{29}$ convinced neo-liberals. Their political agenda was always going to undermine what the Big Society programme was proposing to build, a warning made by Philip Blond: market economics awkwardly allied with a compassionate and impotent version of socially concerned conservatism. One need only look at the rampant levels of inequality produced by George Bush's American variant of the same procrustean marriage. ${ }^{30}$

Heedless or complicit, Cameron allowed his Government's economic agenda to take precedence over his social agenda and the Big Society now seems to be moribund. Philip Blond again commented in the Guardian "David Cameron has lost his chance to redefine the Tories." ${ }^{31}$ Philip Blond is mistaken, however, in suggesting that the sole reason for this change of tack is that Cameron was "careless" or that he "surrendered to No 11." Ultimately politicians respond to what they think their voters want.

19 Most surveys point to a British ${ }^{32}$ society that is growing increasingly individualistic rather than the opposite, in spite of a double-dip recession affecting employment and drastic public spending cuts. Academics working on the public's response to government policies contend that people tend to respond like a thermostat. ${ }^{33}$ For example, if a government spends a lot of money to support welfare reforms, the public will tend to react against such increases and advocate either moderation or cuts. This is a consideration that needs to be taken into account when analysing the results of the BSA survey of 2010 that revealed that a majority of respondents were opposed to the New Labour tax-and-spend policies. Following the same pattern, one might expect that after years of Conservative/ Liberal Democrat rule characterized by drastic public sector cuts, especially in Welfare, and a double dip recession, the British society's attitude might have changed again. However, according to the $30^{\text {th }}$ British Social Attitudes Survey published in September $2013^{34}$, this was not so. People's attitude especially towards benefits recipients remained almost the same as it was in 2010: from 55\% who said that "if welfare benefits weren't so generous people would learn to stand on their own two feet" to 53\% in 2012. In some cases, people's attitude hardened, as is the case towards the recipients of unemployment benefits. In 2011, 61\% supported the view that unemployment benefits were "too high and discouraged work" (51\% in 2010). There exist differences that tend to show that the gap between different social groups is widening but that also demonstrate that irrespective of 
party affiliation or occupational class, a fair number of respondents still judge unemployment benefits recipients negatively. In 2011, 77\% of respondents affiliated to the Conservative Party and 65\% belonging to the "professional class" agreed that unemployment benefits were "too high and discouraged work," respectively a 21 and 25 percentage point increase on 2003. 55\% of respondents affiliated to the Labour Party and the same percentage of Liberal Democrats agreed with this proposition. $66 \%$ of the middle class (intermediate) and $58 \%$ of the working class (routine) also did. In all these cases, the percentage had increased from 2003.

According to the Community Life Survey: England, 2013-2014, ${ }^{35} 29 \%$ of people reported that they volunteered formally ${ }^{36}$ at least once a month in $2005,25 \%$ in $2010-11$ and $27 \%$ in 2013-14. ${ }^{37}$ Many factors come into play when determining whether an individual will or will not volunteer but time, money and social capital are those most commonly invoked by both specialists, such as the National Council for Voluntary Organisations (NCVO) for example, and respondents. The $29^{\text {th }}$ BSA published in 2012 reveals that $22 \%$ of respondents, men and women, had had to take a pay cut in the years between 2009 and 2011. An increasing number of respondents complained of working "un-social hours" (nights, weekends, etc.), the percentage being more important amongst women than men. Finally $89 \%$ were "too tired after work to enjoy things at home," a 16 percentage point increase on 2004. In addition, a report from NCVO published in September $2011^{38}$ highlighted that participation, whether civic or through voluntary work, depended mostly upon socio-economic factors, social capital being a determining factor in this respect. Most citizens involved in charity work were skilled, educated, belonged to the majority ethnic group and were women: "The typical formal volunteer is more likely to be female, of a higher social grade, in a managerial position, degree educated, and middle aged." 39 The typical formal volunteer was thus an individual who had the sort of background or " felt resources" ${ }^{\prime 40}$ most likely to give her/him what NCVO describes as the necessary confidence to engage with others..$^{41}$ It is easy to imagine what sort of consequences this might have. Volunteering is, by definition, the act of engaging in one's community and indeed, the principle behind the Big Society is that members of a community know better than the central government what is best for them. ${ }^{42}$ The Community Life Survey revealed that in 2013-14, a significantly lower percentage of people $(60 \%)$ agreed that people in their neighbourhood pulled together to improve it than in 2007-08 (68\%). ${ }^{43}$ In addition to decreasing, this percentage was significantly smaller in deprived neighbourhoods. The first audit of the Big Society released on $7^{\text {th }}$ May $2012^{44}$ showed that only $51 \%$ of respondents living in "the most deprived areas" believed their "neighbourhood pulls together to improve it" compared to $78 \%$ in more affluent areas. This confirms that the communities that most need the Big Society are those that are least likely to have the social capital to form a Big Society. As was the case in the $19^{\text {th }}$ century, active citizenship in the form of volunteering is still a class activity. This, in turn, explains why, in the most deprived areas, voluntary action is largely dependent on statutory funding by local authorities. However, those authorities with the highest level of deprivation in Britain are also those that suffered the deepest cuts in spending in 2011-12. ${ }^{45}$

\section{Conclusion}

21 For the last thirty years, citizens have been told by politicians and media alike that they had to look after themselves rather than after the recipients of welfare benefits (through 
tax and spend policies). Marshall's social citizenship has thus been under attack since Margaret Thatcher's Conservative Party formed a government in May 1979, a trend that was not fundamentally reversed under New Labour. The result is that a majority now hold negative views of benefits recipients and this attitude does not seem to have been affected by the recession and the Coalition Government's drastic public spending cuts. However, at the same time as implementing these cuts, David Cameron consistently tried to exhort "families, individuals, charities and communities" to "come together to solve problems $"{ }^{46}$ heedless of the contradiction between conflicting messages: on the one hand arguing that for the state to give help is counterproductive and has the adverse effect of rendering the beneficiaries helpless, and on the other hand exhorting citizens to give their time and/or money to the volunteer sector for them to provide for the weaker in society, ultimately the very same people. Obviously, David Cameron's aim in proposing an alternative to Marshall's social citizen and to Margaret Thatcher's "no society", i.e. the citizen of his Big Society, was to ask civil society to do what the state would no longer do.

However, the combined effect of British society's negative attitude to the poorer part of society and the economic crisis, which has contributed to deteriorated working conditions and loss of income, has adversely affected the third sector. The worst hit regions are those in which unemployment and poverty were the highest - unsurprisingly so, for volunteering is still a class activity.

On $13^{\text {th }}$ June 2014, there were 5,112 listed charities in the North East of England compared to 29,238 in the South East. ${ }^{47}$ In other words, there were 1,966 charities per million residents in the North East compared to 3,400 in the South East, i.e. almost twice as many for the affluent South East. If the Big Society was meant to replace the Big Government, by June 2014 this had only happened in the most affluent parts of Britain and a more indepth analysis of the type of charities most present would certainly reveal that their work had little to do with the recipients of state welfare.

The impression is that the transplant from Marshall's liberal citizen to the neo-liberal active citizen has taken. However, what has occurred, as a result, is not a revival of civil society with active citizens taking over the role of the welfare state but a privatization of citizenship for some and exclusion for others.

Raphaelle Espiet-Kilty is a lecturer in British Studies in the English department at the Université Blaise Pascal Clermont II. She is a specialist in Contemporary Political History. Her research is on the place of citizens in the social policy of Conservative governments since 1979. She edited the 17th issue of L'Observatoire de la société britannique, "The Thatcher Legacy ", published in November 2015.

\section{BIBLIOGRAPHY}

Alexandre-Collier, A., Les Habits neufs de David Cameron : Les conservateurs britanniques (1990-2010)

(Paris, Les Presses de Sc. Po, 2010).

Bale, T., Five Year Mission (Oxford, Oxford University Press, 2015). 
Bale, T., The Conservative Party from Thatcher to Cameron (Cambridge, Polity Press, 2010).

Bale, T., The Conservatives since 1945: The Drivers of Party Change (Oxford, Oxford University Press, 2012).

Bochel, H. (ed.), The Conservative Party and Social Policy (Bristol, The Policy Press University of Bristol, 2011).

Cabinet Office, The Giving White Paper, Cmd 8084, 23 May 2011, < https://www.officialdocuments.gov.uk >.

Cameron, D., speech on the Big Society, November 2009, <www.conservatives.com/News/ Speeches/2009/11/Cameron>.

Cameron, D. and Jones, D., Cameron on Cameron: Conversation with Dylan Jones (London, HarperCollins, 7 January 2010).

Community Life Survey, all publications, < https://www.gov.uk/ >

D’Ancona, M., In It Together: The Inside Story of the Coalition Government (London, Viking, 2013).

Dorey, P., British Conservatism. The Politics and Philosophy of Inequality (London, I.B. Taurus \& Co Ltd., 2011).

Espiet-Kilty, R., "David Cameron and the Big Society: A New Deal for the New Citizen?", Observatoire de la Société Britannique 12 (October 2012), pp. 49-68, "La nouvelle donne politique en Grande-Bretagne (2010-2012)".

Faulks, K., Citizenship in Modern Britain (Edinburgh, Edinburgh University Press, 1998).

Gamble, A., The Free Economy and the Strong State: The Politics of Thatcherism (Basingstoke, Macmillan, 1988).

Hayek (von), F., Law, Legislation and Liberty. Volume II: The Mirage of Social Justice (Chicago, University of Chicago Press, 1978).

Hilton, M. and McKay, J. (eds), The Ages of Voluntarism. How We Got to the Big Society (Oxford, Published for the British Academy by Oxford University, 2011).

Jenkins, S., Thatcher and Sons: A Revolution in Three Acts (London, Penguin, 2007).

Kavanagh, D., Thatcherism and British Politics (Oxford, Oxford University Press, 1990).

Kisby, B., "The Big Society: Power to the People?", The Political Quarterly 81:4 (October-December 2010), pp. 484-491.

Marshall, T.H. and Bottomore, T., Citizenship and Social Class (London, Pluto Press, 1992).

Montgomerie, T. and Gamble, A., "Extraordinary Times in British Politics: A Conversation [online]", Quadrant 59:10 (October 2015), pp. 24-28.

Moore, C., Margaret Thatcher. The Authorized Biography. Volume One: Not For Turning (London, Penguin, 2014).

NatCen, British Social Attitudes Survey Reports, <www.bsa.natcen.ac.uk/>.

National Council for Voluntary Organisations, Participation: Trends, Facts and Figures, March 2011,< http://www.ncvo.org.uk/ > .

National Council for Voluntary Organisations, Pathway through Participation: What Creates and Sustains Active Citizenship?, Briefing Paper n³ (September 2011). 
Parker, R., "Little Platoons and Problems with Pluralism", The Political Quarterly 82:1 (JanuaryMarch 2011), pp. 50-55.

Seldon, A. and Snowden, P., Cameron at 10, the Inside Story 2010-2015 (London, William Collins, 2015).

Stewart, A., “Two Conceptions of Citizenship”, The British Journal of Sociology 46:1 (March 1995), pp. 63-78.

Tam, H., "The Big Con - Reframing the State / Society Debate", Public Policy Research 18:1 (MarchMay 2011), pp. 30-40.

Taylor-Gooby, P. and Stoker, G., "The Coalition Programme: A New Vision for Britain or Politics as Usual?", The Political Quarterly 81:1 (January-March 2011), pp. 4-15.

Thatcher, M., The Downing Street Years (London, Harper Collins Publishers, 1995).

Thatcher, M., The Path to Power (London, Harper Collins Publishers, 1995).

Thatcher, M., speech to the General Assembly of the Church of Scotland, 21 May 1988, < www.margaretthatcher.org/document/107246 >.

Thatcher, M., TV Interview for London Weekend Television, “Weekend World”, January 1983, < http://www.margaretthatcher.org/speeches/displaydocument.asp?docid=105087 >.

Wilding, P., “The British Welfare State: Thatcherism's Enduring Legacy”, Policy \& Politics 20:3 (July 1992), pp. 201-212.

\section{NOTES}

1. Robert Harmel and Kenneth Janda, "An Integrated theory of Party Goals and Party Change", Journal of Theoretical Politics 63:3 (1994), pp. 259-287 quoted in Tim Bale, The Conservatives since 1945. The Drivers of Party Change (Oxford, Oxford University Press, 2012), p. 3.

2. Ibid, p. 4.

3. Ibid, p. 5. I will not elaborate further on this analysis of party change for it is not my subject proper. However, I do not wish to give an over simplistic view of Tim Bale's book. Obviously, the drivers which were chosen here are only the most commonly used ones. They are not, in any way, the only ones.

4. The term "nasty party" to describe the Conservative Party was first given public airing by Teresa May, the then Chairman, in October 2002: "There's a lot to do in this party of ours. Our base is too narrow so, occasionally, are our sympathies. You know what some people call us - the Nasty Party". The expression was then taken up by the then leader of the Conservative Party, Iain Duncan Smith, who repeatedly insisted that the party needed to rid itself of its image of "nasty party". David Cameron also endeavoured to convince voters that his Conservative Party was no longer the nasty party, i.e. a party that did not have sympathy for those at the bottom of society, for the less privileged, for the minorities, the party that also wanted to bring free market economics into health and education.

5. D. Cameron and D. Jones, Cameron on Cameron: Conversation with Dylan Jones (London, HarperCollins, 7 January 2010).

6. Officially, the status British Citizen first appeared in 1981 (British Nationality Act) when it replaced that of British Subject. Since then, citizenship and nationality have become closely linked, to the point that it is sometimes difficult to distinguish them. I do not agree that citizenship and nationality are one and the same thing but to discuss this particular issue is not the object of this article. 
7. Van Gunsten (1978) and Leca (1991) are quoted in A. Stewart, "Two Conceptions of Citizenship", British Journal of Sociology 46:1 (March 1995), pp. 63-78.

8. Ibid, p. 65.

9. The term was first coined by Douglas Hurd at the Conservative Party Conference of 1988. I would argue that it was the party's attempt to spin Margaret Thatcher's "There is no such thing as society" that had made considerable stir. It also preceded the introduction of the community charge. For a discussion on the possible reasons why the term made a return, see Raphaële Espiet-Kilty, "David Cameron and the Big Society: a New Deal for the New Citizen", Observatoire de la Société Britannique 12 (October 2012), "La nouvelle donne politique en Grande-Bretagne (2010-12)", pp. 50-51.

10. T.H. Marshall and T. Bottomore, Citizenship and Social Class (London, Pluto Press, 1992).

11. Ibid, p. 2.

12. Ibid.

13. Agnès Alexandre-Collier, Les Habits neufs de David Cameron: Les conservateurs britanniques (1990-2010) (Paris, Les Presses de Sc. Po, 2010).

14. Stuart Hall, "The March of the neoliberals", The Guardian, 12 September 2011; Richard Grayson, “Clegg and Cameron's illiberal 'Big Liberal Society”, The Guardian, 20 July 2010; H. Tam, "The Big Conservative Reframing the State/Society Debate", Public Policy Research 18:1 (JanuaryMarch 2011), pp. 30-40; P. Taylor-Gooby and G. Stoker, "The Coalition Programme: A New Vision for Britain or Politics as Usual?", The Political Quarterly 82:1 (January-March 2011), pp. 4-15.

15. This term was first coined by the Libertarian political scientist Charles Murray in Losing Ground: American Social Policy 1950-1980 published in 1984. It was commonly used by Margaret Thatcher during the debate over the community charge and was used again in her memoirs, for example in The Path to Power (London, Harper Collins Publishers, 1995), pp. 544, 561 and 599, and in The Downing Street Years (London, Harper Collins Publishers, 1995), pp. 627, 661.

16. Interview on 23 September 1987 for Women's Own, a woman's magazine. A transcript of the interview is presented by the Thatcher Foundation, <www.margaretthatcher.org/ document/106689>. It differs slightly from the original version.

17. Mathew Hilton and James McKay (eds), The Ages of Voluntarism. How We Got to the Big Society (Oxford, Oxford University Press, 2011), p. 7.

18. Margaret Thatcher, Speech to the General Assembly of the Church of Scotland, 21 May 1988, < www.margaretthatcher.org/document/107246>

19. Friedrich von Hayek, Law, Legislation and Liberty. Volume II: The Mirage of Social Justice (Chicago, University of Chicago Press, 1978), p. 78.

20. Margaret Thatcher, Interview for London Weekend Television "Weekend World", 16 January 1983, <http://www.margaretthatcher.org/speeches/displaydocument.asp?docid=105087>

21. Peter Dorey, British Conservatism. The Politics and Philosophy of Inequality (London, I.B. Taurus \& Co Ltd., 2011).

22. Social Justice Group, Breakdown Britain. Interim Report on the State of the Nation, December 2006.

23. British Social Attitudes Survey, $27^{\text {th }}$ Report, <www.bsa.natcen.ac.uk/>.

24. Agnès Alexandre-Collier, Les Habits neufs de David Cameron, op. cit., p. 11.

25. P. Taylor-Gooby and G. Stoker, op. cit., pp. 4-15, p. 7.

26. David Cameron, speech on the Big Society, November 2009, <www.conservatives.com/News/ Speeches/2009/11/Cameron>.

27. See H. Tam, op. cit., and P. Taylor-Gooby and G. Stoker, op. cit., amongst others.

28. The "vile product" was Mick Philpott. See Daily Mail, 2 April 2013.

29. After the May 2015 victory, David Cameron maintained George Osborne and Ian Duncan Smith respectively as Chancellor of the Exchequer and Secretary of State for Work and Pensions.

30. Philip Blond, Red Tory. How Left and Right have Broken Britain and how we can Fix It (London, Faber and Faber limited, 2010), p. 33. 
31. The Guardian, 3 October 2012.

32. The surveys mentioned here usually study England and Wales together. There are separate surveys for both Northern Ireland and Scotland. And of course, the population census that can be used as a basis for most statistical presentation of demographic, economic and social trends exemplifies this difference. Any statistical reference to Britain here therefore excludes Northern Ireland and Scotland unless stated otherwise.

33. See Wlezien, Curtice and Defty, quoted in Hugh Bochel (ed.), The Conservative Party and Social Policy (Bristol, The Policy Press University of Bristol, 2011).

34. British Social Attitudes Survey, $30^{\text {th }}$ Report, <www.bsa.natcen.ac.uk/>.

35. Cabinet Office, Community Life Survey: England, 2013-2014, Statistical Bulletin (London, July 2014),

<https://www.gov.uk/government/collections/community-life-survey>.

36. Formal volunteering is defined as the act of "giving unpaid help through groups, clubs or organisations"; see ibid, p. 6.

37. Ibid, figure 3 , p. 8.

38. NCVO, Pathway through Participation: What Creates and Sustains Active Citizenship? Briefing Paper $\mathrm{n}^{\circ} 3$ (NCVO, September 2011).

39. Ibid., p. 3.

40. Ibid, p. 5.

41. Ibid.

42. David Cameron, speech on the Big Society, November 2009, <www.conservatives.com/News/ Speeches/2009/11/Cameron>.

43. Community Life Survey, op. cit., Figure 11, p. 16.

44. Big Society Audit, Civil Exchange. Strengthening Society's Connection to Government, 7 May 2012.

45. Ibid, p. 2.

46. David Cameron, speech on the Big Society, November 2009, <www.conservatives.com/News/ Speeches/2009/11/Cameron>.

47. See < http://www.charitychoice.co.uk >, consulted on 13 June 2014.

\section{ABSTRACTS}

David Cameron's Big Society Programme was his flagship programme for the 2010 general election. Its main objective was to help the Conservative Party distance itself from Thatcherism, notably by bringing about change for Britain's society. The government was to help society regenerate itself by giving British citizens the means to look after their communities. Was the Big Society the sign that the Conservative Party had managed to break away from Thatcherism? Was it the programme of a whole party or just the Prime Minister's “toy"? Did the programme find an echo amongst British citizens?

Le Big Society Programme du candidat David Cameron pour les élections du printemps 2010 avait pour objectif principal de renouveler l'image du Parti conservateur dans son rapport à la société. Il s'agissait de redynamiser la société civile en aidant les citoyens à prendre une place prépondérante, notamment sur le terrain du social. Trois questions se posent : ce projet était-il le signe d'un retour du conservatisme compassionnel, par définition différent du conservatisme néolibéral de Margaret Thatcher? Le programme de Big Society était-il porté par tous les 
membres du gouvernement de coalition de 2010-15 ou était-il le «jouet » du seul Premier Ministre? A-t-il trouvé une résonnance auprès des citoyens britanniques?

INDEX

Keywords: citizenship, Thatcherism, Big Society, civil society, volunteering Mots-clés: citoyenneté, thatchérisme, Big Society, société civile, bénévolat.

\section{AUTHOR}

\section{RAPHAËLE ESPIET-KILTY}

Université Blaise Pascal-Clermont II, EHIC 